"Mircea cel Batran" Naval Academy Scientific Bulletin, Volume XIX - 2016 - Issue 1

Published by "Mircea cel Batran" Naval Academy Press, Constanta, Romania // The journal is indexed in:

PROQUEST / DOAJ / DRJI / JOURNAL INDEX / I2OR / SCIENCE LIBRARY INDEX / Google Scholar / Crossref /

Academic Keys / ROAD Open Access / OAJI / Academic Resources / Scientific Indexing Services / SCIPIO

\title{
THE TIME FACTOR IN MARITIME TRANSPORT AND PORT LOGISTICS ACTIVITIES
}

\author{
Florin NICOLAE ${ }^{1}$ \\ Alexandru COTORCEA ${ }^{2}$ \\ Marian RISTEA ${ }^{3}$ \\ Iulian ROMAN ${ }^{4}$ \\ ${ }^{1}$ Associated Professor, Ph.D., "Mircea cel Batran" Naval Academy, Constanta, Romania \\ ${ }^{2}$ Ph.D. attendee, "Mircea cel Batran" Naval Academy, Constanta, Romania \\ ${ }^{3}$ Associated Professor, Ph.D., "Mircea cel Batran" Naval Academy, Constanta, Romania \\ ${ }^{4}$ Ph.D. attendee, Technical Academy, Bucharest Romania
}

\begin{abstract}
Execution of the carriage contract requires compliance to all the conditions in it, by all those involved in the transport. Main obligations incumbent upon the vessel, and obviously, to other transporters, who must provide transportation according to deadlines and safety. Contract compliance is certifying transport participants about their seriousness and an appropriate market quotation. Therefore, present work pragmatically sets schematics reference time associated to implementation of the carriage contract. Also, are demonstrated relationships established between maritime transport "players" and sequence of activities related to the operation of the vessel in port. The authors propose a set of concepts and terms whose utility is established to solve practical problems in this area of activity.
\end{abstract}

Key words: maritime transport, contract of carriage, reference time.

\section{Introduction}

Systematic record of time and workload is the fundamental principle underlying increase of efficiency within any organization [1]. Viewed from a managerial perspective, time is the resource that cannot be replaced. Although, Time is money is attributed to Benjamin Franklin (1748), surely it was put in value ever since antiquity. Today all managers who seek performance, start from the

fact that time is continuous and measurable and time management is a priority for achieving profit [2]. For policymakers, regardless of the type of activity managed, it is considered that the first step towards the achievement of effective leadership is rational use of time and, the next step is crucially determined by its organization [3].

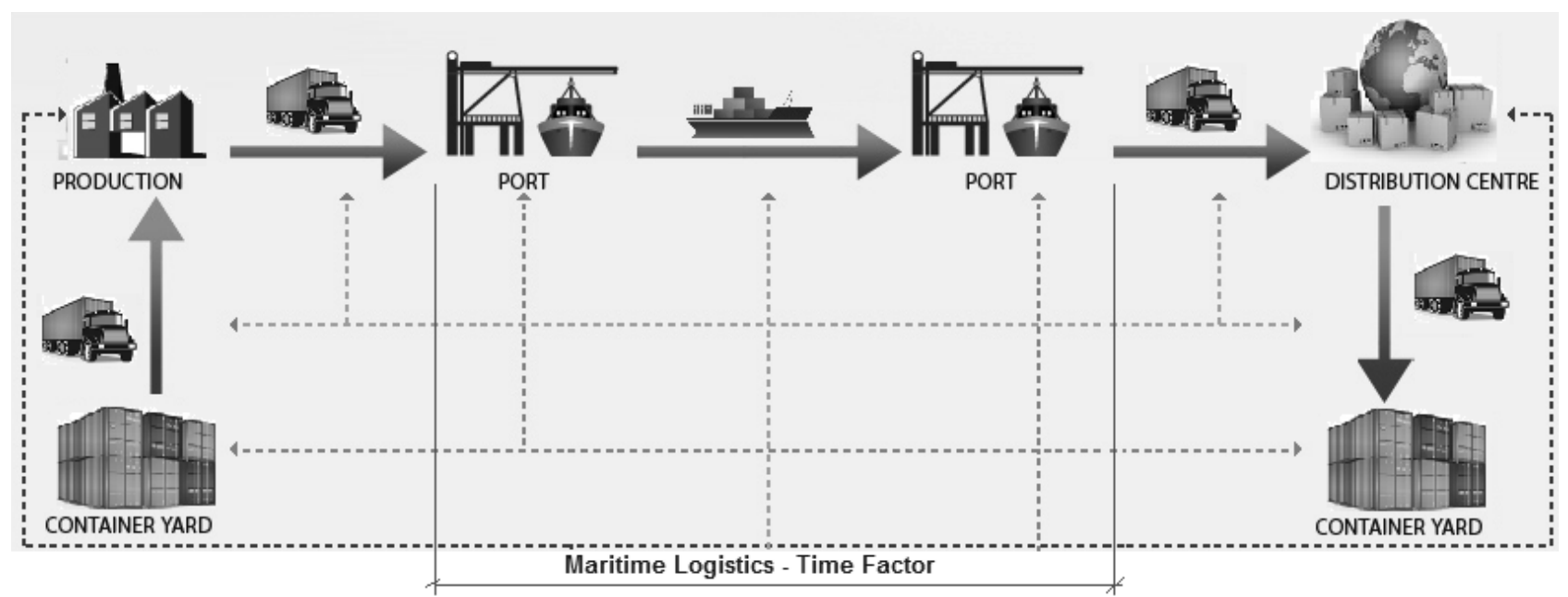

Figure 1. Maritime Logistics in Supply Chain Management

The reasons set out above, maritime affairs, through shipping and port logistic activities, is an integrated logistics activity, Figure 1. This system is limited to transship goods through handling, transport, sorting and storage, for the purposes of physical movement of product from manufacturer to consumer.
Obviously, an efficient manager is envisaged that these activities contained in this supply chain to achieve the lowest cost in the shortest time. For marine and port logistics activities management time factor is an important issue, governed by the contract of carriage. Waiting time, the residence time of the ship under operation, delays due to 
"Mircea cel Batran" Naval Academy Scientific Bulletin, Volume XIX - 2016 - Issue 1

Published by "Mircea cel Batran" Naval Academy Press, Constanta, Romania // The journal is indexed in: PROQUEST / DOAJ / DRJI / JOURNAL INDEX / I2OR / SCIENCE LIBRARY INDEX / Google Scholar / Crossref /

Academic Keys / ROAD Open Access / OAJI / Academic Resources / Scientific Indexing Services / SCIPIO

causes more or less objective, are indicators that determine the performance of a port / terminal port. The approaches in this field of time factor, highlighted in studies and scientific works, are diverse, the problem prompting many points of view [4-7]. In addition to the mentioned research, this paper is based on summary of formal and informal discussions during 2010-2015 with over 150 stakeholders in the maritime industry. We find among them representatives of transport companies (sea, river, rail and road), stakeholders (in port activity, customs clearance, border and port control), ship agency companies, seafarers (captains and deck officers - managerial level). The authors synthesized information related to the reference times, and propose a standardization of terminology used in maritime transport and port logistics activities.

\section{Synthesis of the reference times used in maritime logistics}

The execution of the transport contract requires, first, compliance with all the conditions in it, by all those involved in the transport. Although the main obligations incumbent on ship, and obviously to other carriers that must provide transportation in time and in complete safety and other participants must fulfill their tasks properly. Contract compliance certify on the seriousness and appropriate market quotation of transport participants. For the port to be able to meet its obligations is necessary to know the date on which the ship arrives, type, quantities and particularities of goods and their location on the vessel, so that it can carry out the necessary preparations for loading or unloading.

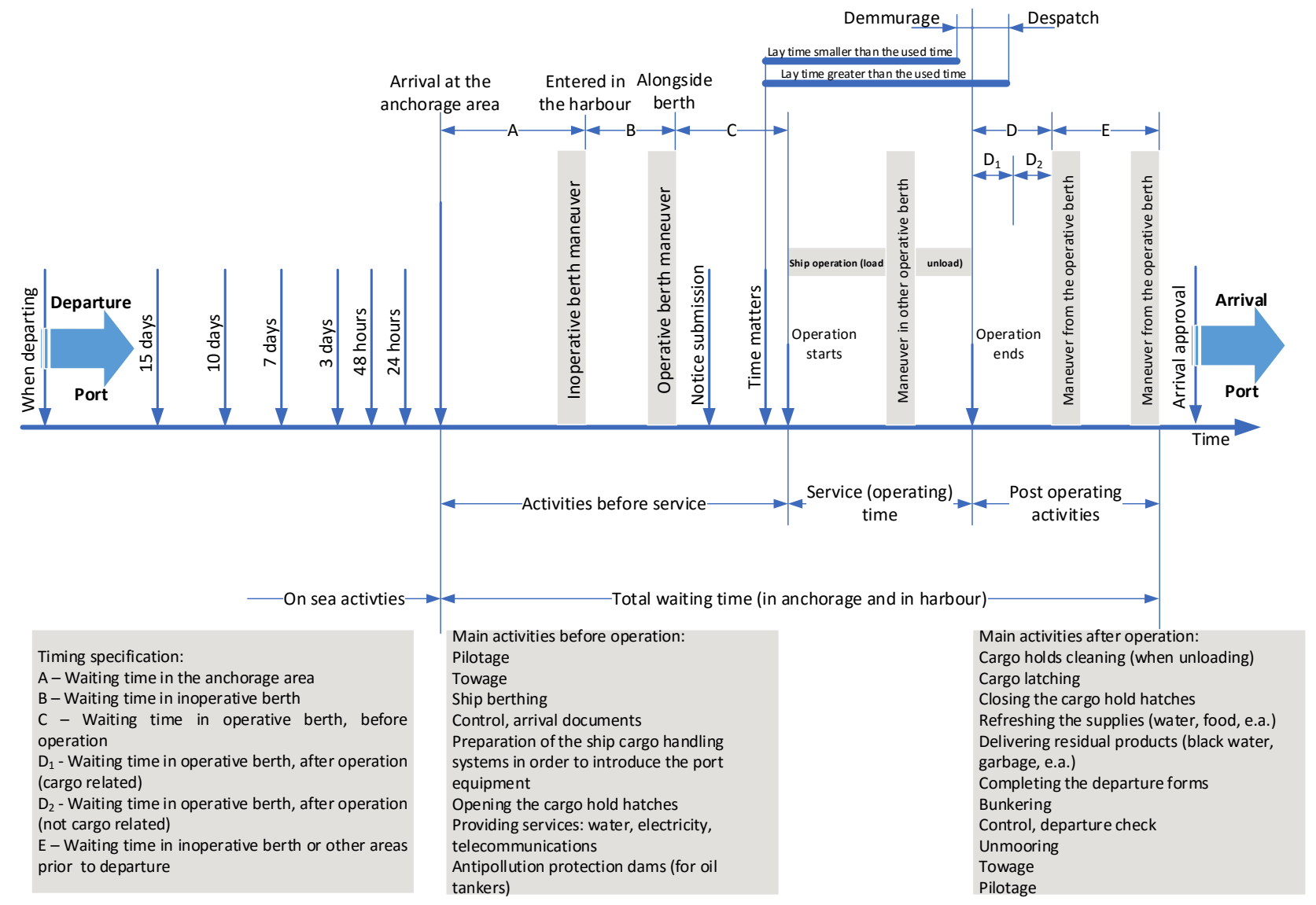

Figure 2. Operations and associated times of maritime logistics

Before operation of the ship, during loading or unloading and also after completion, onboard ship is carried out a series of activities whose start and end time must be thoroughly known in order to determine the duration of activities and their impact on the contract of carriage. Given the great importance of total dwell time in port, calculated on minute, these periods constitute the reference times in determining transport clauses and, consequently, how carriage was implemented. Sequence of ship activities related to stationing and operation to a particular port is shown in Figure 2. Under these conditions, the main 
"Mircea cel Batran" Naval Academy Scientific Bulletin, Volume XIX - 2016 - Issue 1

Published by "Mircea cel Batran" Naval Academy Press, Constanta, Romania // The journal is indexed in: PROQUEST / DOAJ / DRJI / JOURNAL INDEX / I2OR / SCIENCE LIBRARY INDEX / Google Scholar / Crossref /

Academic Keys / ROAD Open Access / OAJI / Academic Resources / Scientific Indexing Services / SCIPIO

reference time which characterizes these activities

are represented schematically in Figure 3.

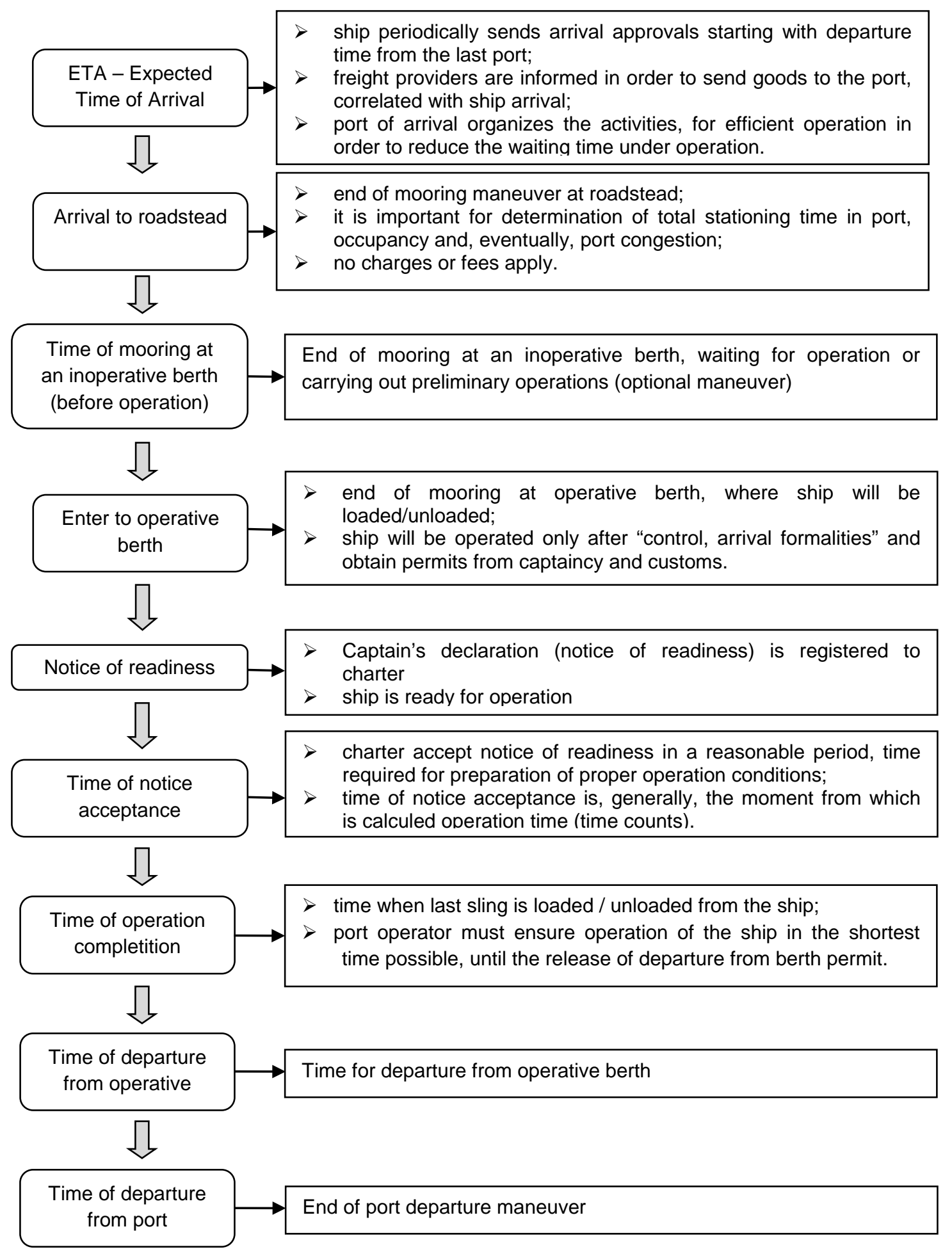

Figure 3. Reference times in the relationship between maritime transport and port logistics activities

The complexity of shipping activities and actions require a rigorous time management by programming, anticipating and proper reaction to all actors involved (from the ship and port), in a planned manner, predictive, efficient and effective.

DOI: 10.21279/1454-864X-16-I1-013

(C) 2015. This work is licensed under the Creative Commons Attribution-Noncommercial-Share Alike 4.0 License.
Therefore, further there will be detailed reference times represented in Figure 3.

a) Notice of arrival (ETA - Expected Time of Arrival). Allow the port to take the necessary actions to operate as efficiently as possible and reduce stationing time. The arrival of the ship 


\begin{abstract}
"Mircea cel Batran" Naval Academy Scientific Bulletin, Volume XIX - 2016 - Issue 1
Published by "Mircea cel Batran" Naval Academy Press, Constanta, Romania // The journal is indexed in: PROQUEST / DOAJ / DRJI / JOURNAL INDEX / I2OR / SCIENCE LIBRARY INDEX / Google Scholar / Crossref /

Academic Keys / ROAD Open Access / OAJI / Academic Resources / Scientific Indexing Services / SCIPIO
\end{abstract}

known sooner, provide port more time for preparation for operation of the ship. The arrival of the ship is especially important for ships that are loading, allowing providers to correlate delivery of cargo with ship arrival. Due to hydro meteorological conditions and not knowing the actual duration of stationing in previous ports, the notified date is uncertain. This is why most port regulations require periodic notifications from ships, becoming in this way more accurate. Usually the vessel is obliged to announce the date of arrival in port at the departure from the last port and repeat at intervals set by days. The last approval will be submitted 24 hours before arrival, when there will be communicated the exact arrival time [8 - 9].

b) Arrival to roadstead - is the moment of completion of accosting at roadstead, respectively once the pilot descends on board (if arrival was done with pilot on board) or the moment that anchor is dropped in roadstead or inner harbor (if arrival was done without pilot on board). Although this time has no relevance to the agreement, unless it is expressly stipulated, it is nevertheless important for determining the total stationing time in port, occupancy and congestion of the port [8]. During stationing in port roadstead no fees or taxes are applying, as opposed to situation when the vessel is stationary in inner harbor.

c) Time mooring at an inoperative berth, before operation, is the moment of completion of accosting at one of the port berths or at an inoperative berth while pending for operation. For entry into port, ship must obtain an entry permit from the harbor master's office and is considered came into port and moored at the end of berthing maneuver. This phase should normally be eliminated, by direct accosting of ship on operative berth. In this case, the entry into port is equivalent entry at the berth.

d) Entry at the operative berth (mooring at first operative berth) is the moment of completion of maneuver and mooring at the berth where the vessel will be loaded or unloaded. Before any operations, immediately after mooring, the vessel must obtain "free practice" permit (if docked directly into the berth), which is granted by the state authorities for sanitary and phytosanitary control; it certifies that the vessel is safe to humans, animals or the environment and sanitary and phyto-sanitary regulations are respected. After performing the sanitary and phytosanitary control, the harbor master's office, customs officials and border police perform further checks. All these operations, where the ship, after inspection, is declared suitable for operation, are commonly called "control, arrival formalities". Sometimes these operations can be executed in roadstead or at inoperative berth. Operation of the ship is allowed only after the release by the Harbor master of mooring permit and by customs of loading / unloading permit.

e) Depus notice (notice's submission date) is when the captain's declaration (notice of readiness) is registered, by declaring that the ship is ready for loading and that its operation can begin. From this moment the ship is available, any delay in starting the operation being the attribute of charter. Notification should be submitted: to the ship cargo unloading ports; to the ship cargo loading ports, even if the vessel has unloaded in the same berth; in each port, even if some of these ports are very close; if it was delivered by radio (notice must be delivered printed). Liners are not obliged to submit "notice of readiness", because they are available to charter immediately after arrival control.

f) Time counts (notice's acceptance date). Charter should not accept the notice immediately, but in a period of time, period determined for each port by its own regulations called "breathing period", time considered necessary for preparing and providing the actual operating conditions of the ship. Notice acceptation date is, in most cases, the moment from which operation time (stipulated in the contract) is calculated. The port operator cannot refuse to accept the notice only if there are suspicions or observations, subsequently confirmed by a competent expertise, that the ship has malfunctions which may affect the safety of the operation or has interdictions given by authorities at arrival inspections.

g) Operation start (time of commencement of operation) is the starting time of the effective operation of the ship, marked by the presence on board of work team (team leader, dockworkers, mechanics, etc.) and representatives of charter

h) Operation completed (time of completion of operation) is when the last cargo sling is loaded or unloaded from the vessel. It does not require the simultaneous completion of all ship barns, how it is planned and carried out ship operation being port operator decision which must ensure operation of the ship as soon as possible. Operations are allowed only until the release of departure from berth permit.

i) Departed from berth (time of departure from the operative berth) is the start of the departure maneuver from operative berth, whether subsequently ship will moor at an inoperative berth or will directly leave port.

j) Departed from port (time of departure from port) is the time of completion of departure from port maneuver. Before leaving port, the ship is inspected by the competent authorities (captaincy, customs and border police) and receive departure 


\begin{abstract}
"Mircea cel Batran" Naval Academy Scientific Bulletin, Volume XIX - 2016 - Issue 1
Published by "Mircea cel Batran" Naval Academy Press, Constanta, Romania /I The journal is indexed in: PROQUEST / DOAJ / DRJI / JOURNAL INDEX / I2OR / SCIENCE LIBRARY INDEX / Google Scholar / Crossref /

Academic Keys / ROAD Open Access / OAJI / Academic Resources / Scientific Indexing Services / SCIPIO
\end{abstract}

permit. Immediately after leaving the port, ship shall submit notice of arrival for next port.

\section{Times associated with ship stationing in port}

As stated, to determine the position and situation of ship is enough to know ship maneuvers during stationing in port. Depending on these maneuvers, the following main activities periods can be defined in the port:

a) Stationing (waiting) in roadstead. Except in extraordinary circumstances which cannot be attributed to port (quarantine, the presence onboard of illegal people, the existence of goods which require special permits or inspections such as nuclear or toxic, malfunctions that make impossible ship operation etc.) stationing in roadstead should be avoided. It indicates lack of sufficient handling capacity of the port or its poor performance, and is typically generated by port congestion. Stationg in roadstead increases, usually unjustify, the total stationing time of ships in port, which is for ship-owners the main indicator of the efficiency of a port.

b) Stationing (waiting) in non-operative berth. This stationing, unless that was required by the vessel, indicates the same situations as roadstead stationing, except that in this case the ship-owner expenses increase due to port fees and charges. Usually, port cannot impose the vessel to berth before operation, but it can accept it if the ship requires this.

c) Stationing at operative berth before operation commencement. This stationing is required for arrival inspection and should be reduced as much as possible, especially for liners vessels or whose stationary generates high expenses (oil tankers, ore carrier, etc.). The port operator must be ready to start operating the vessel immediately after completion of arrival formalities, in order to reduce the stationing of ship at berth, which is a benefit to both vessel (which will spend less for stationing) and port operators (through the possibility of operate other vessels).

d) Stationing at operative berth after finishing operations, which can be divided into:

- Stationing after operation in relation to cargo represent the time necessary to complete loading/unloading (securing cargo on deck, landing material used for stacking, cleaning barns, degassing of cargo tanks etc.) and is included in time allocated for operation of the ship at berth;

- Stationing after operating unrelated to cargo, is represented by a series of activities and formalities connected with the preparation for departure of the ship such as bunkering, ballasting, garbage and sewage disposal, supply, repair etc. These activities are not attributable to port, and if it takes too much time port is entitled to require that these activities to be carried at inoperative berths, such that operational berth to become available for other vessels; in this case, maneuver to inoperative berth is made on ship's account. For the correct determination of those periods it is necessary to define the maneuver and moments of beginning and end of it.

Maneuver means any movement of vessels in the port traffic control zone, from the entry into this area until leaving it. Start and end of maneuvers are related either to the presence of the pilot on board or the timing of completion of mooring operations. The start of the maneuver is considered, where appropriate, boarding of pilot on board, either vessel completion of the quay. Ending of the maneuver is marked by the descent of the pilot or termination of tying the ship to the berth and, for the maneuvers in roadstead, when anchor is dropped.

The period between start and end of operation of the ship is ship service time (operation) in port. During this period, in which loading and / or unloading is carried out, may occur a number of operating disruptions, some attributable to port, other to ship, while others, such as unfavorable weather, not imputable to both parties. Deal with these interruptions (including the maneuvers performed in this interval) is specified in terms of a charter or is determined by the port practice (uzo porto) if for certain situations there is no appropriate stipulations in the contract.

\section{Indicators of services associated with the} stationing time of the ship in port

Interviewing stakeholders, highlighted the need to substantiate a set of services indicators, to be used in measuring quality of port services provided to users (ship-owners, ship operators, importers and exporters, transporters etc.). The analysis showed that the most important are those related to stationing time of the ship in port. The authors synthesized a set of indicators, which offer indexes on speed of operations in port and represents an important element in estimating the cost of shipping $[7,10]$.

4.1. Total residence time of a vessel in port ( $\boldsymbol{T}_{\text {port }}$ ) is defined as the time elapsed between the time of arrival in port and the departure. The total residence time of the ship in port is usually measured in hours. It is a basic indicator in terms of shipowners and port authorities in an attempt to appreciate how effective are services provided to ships. Generally, total residence time of the ship in port is divided into:

a) Waiting time until operation ( $\mathrm{T}_{\text {wo }}$ ), is the time between arrival and mooring at operating berth (end of maneuver). This time can be very high when there are no free berths for ship operation or when there are particular events (strikes, natural 


\section{"Mircea cel Batran" Naval Academy Scientific Bulletin, Volume XIX - 2016 - Issue 1 \\ Published by "Mircea cel Batran" Naval Academy Press, Constanta, Romania // The journal is indexed in: PROQUEST / DOAJ / DRJI / JOURNAL INDEX / I2OR / SCIENCE LIBRARY INDEX / Google Scholar / Crossref / \\ Academic Keys / ROAD Open Access / OAJI / Academic Resources / Scientific Indexing Services / SCIPIO}

disasters and other force majeure, port congestion etc.);

b) Stationing time at berth $\left(T_{\text {berth }}\right)$ is the time between mooring of the ship at operating berth (end of maneuver) and the vessel's departure from the berth (the start of the departure maneuver). The stationing time of the vessel to berth represents the total time spent at operating berth, whether the ship is operated or not. Highlighting this time is important because it determines the berth occupancy (when taking into account all ships stationed at berth in a specified time period, usually one year). This time must include the time necessary for maneuvers between operating piers (if no other criteria apply, maneuver time is distributed equally between the two berths) and should be excluded berth stationing times unrelated directly to cargo (bunkering, ballasting, repairs, etc.);

c) Ship service time ( $\left.T_{\text {serv }}\right)$ is the period between start of operation and the end of it. This time is included in the stationing time of the ship at berth, but does not include waiting time at berth before and after operation. Normally, here should not be included timeouts generated by vessel or

$$
T_{m p}=\frac{\sum T_{\text {port }}}{N_{\text {ships }}} ; T_{m b}=\frac{\sum T_{\text {berth }}}{N_{\text {ships }}} ; T_{m s}=\frac{\sum T_{\text {serv }}}{N_{\text {ships }}} ; T_{m w o}=\frac{\sum T_{\text {wo }}}{N_{\text {ships }}} ; T_{\text {mao }}=\frac{\sum T_{a o}}{N_{\text {ships }}}
$$

where: $T_{m p}, T_{m b}, T_{m s}, T_{m w o}$ and $T_{m a o}$ are average stationing times in port, at berth, in service, waiting for operation and after operation; $\Sigma T_{\text {port }}$, $\Sigma \mathrm{T}_{\text {berth, }} \Sigma \mathrm{T}_{\text {serv }} \Sigma \mathrm{T}_{\text {wo }}$ and $\Sigma \mathrm{T}_{\text {ao }}$ represents the sum of times mentioned before, calculated for all ships that enter into port in considered period; $\mathrm{N}_{\text {ships }}$ is the number of vessels that stationed in port.

The total average waiting time of ships in port (inoperative time) is: unfavorable weather, when vessel operation was not possible (in any case, they must be separated);

d) Stationing time in port, after operation ( $\left.T_{\text {ao }}\right)$ is the stationing overtime for various activities that are not directly related to ship operation (repair, bunkering, gassing etc.). This time should be subtracted from total stationing time of the ship in port. The time required for activities related to the operation of the ship, such as cargo securing, formalities for vessel's departure, customs clearance etc. must be included in the total stationing time of the ship in port, even if these activities are performed in other berth than operating berth;

e) Total waiting time in port $\left(\mathrm{T}_{\mathrm{w}}\right)$ is determined as the difference between total stationing time and ship service time in port.

4.2. Average times for the above categories are calculated for a determined and significant period of time, usually one year, by summing the times for all ships that reached port in that period and it's dividing to total number of vessels taken into account:

\section{CONCLUSIONS}

The analysis conducted shows that to be significant, times must be determined on types and groups of cargo, berths or according to their specialization and eventually on ships classes. Indicators of average stationing time, even determined under previous conditions, provides only an overview on how the analyzed port operates. For an analysis made by the management of a port, more important are the reports that are established between those indicators that give the rating on how time is used in port by vessels. For example, an important indicator is the ratio of the average service time and average of total stationary time of the ship in port; it should have values as close to $100 \%$. A low value of this indicator indicates poor efficiency of the port or excessive occupancy, and require appropriate measures to enhance this ratio.

Ship's waiting time after operation, obviously directly related to the operation of the ship, should be minimized. The reduction depends on the capacity of ship's management and its agent to solve all problems during operation and the willingness and ability of port authorities to reduce as much as possible the time required for the exercise of their duties after vessel's operation (eg customs, border and other departure formalities etc.).

These times, in hours, will be calculated for those vessels which have operated in analyzed berths, even if for example, the waiting time can be strongly influenced by the performance of another group of berths (in terms of characteristics, usage or specialization). 
"Mircea cel Batran" Naval Academy Scientific Bulletin, Volume XIX - 2016 - Issue 1

Published by "Mircea cel Batran" Naval Academy Press, Constanta, Romania // The journal is indexed in:

PROQUEST / DOAJ / DRJI / JOURNAL INDEX / I2OR / SCIENCE LIBRARY INDEX / Google Scholar / Crossref /

Academic Keys / ROAD Open Access / OAJI / Academic Resources / Scientific Indexing Services / SCIPIO

Interviewing stakeholders on the analysis of occupancy and use of the berth, led to conclusion that the optimal approach is based on monthly determination. The actual time worked at berth, dead times due to port or for reasons beyond the port (such as unfavorable weather and disruptions due to the ships), will result as the difference between total available time and sum of times mentioned above when berth was free. If records are held by groups of berths, times will be determined as average times.

Information, point of views and conclusions of this paper can be used to analyze the overall performance of port activities (or a specialized port terminal) or performance of shipping companies.

\section{BIBLIOGRAPHY}

[1] Taylor, F. W. (2004). Scientific management. Routledge.

[2] Branch, A., \& Stopford, M. (2013). Maritime economics. Routledge.

[3] Drucker, P. (2014). Innovation and Entrepreneurship. Routledge.

[4] Notteboom, T. E. (2006). The Time Factor in Liner Shipping Services. Maritime Economics \& Logistics, 8, 19-39.

[5] Rodrigue, J. P., Comtois, C., \& Slack, B. (2013). The Geography of Transport Systems. Routledge.

[6] Feo-Valero, M., García-Menéndez, L., \& Garrido-Hidalgo, R. (2011). Valuing freight transport time using transport demand modelling: a Bibliographical Review. Transport Reviews, 31(5), 625-651.

[7] Nicolae F., Ristea, M., Cotorcea A., Nistor, F., 2015. The Relationship Between Port Logistics and Global Logistics Performance. Scientific Bulletin" Mircea cel Batran" Naval Academy,18(1), ISSN 1843-6749, pp. 83-88.

[8] Christiansen, M., Fagerholt, K., \& Ronen, D. (2004). Ship routing and scheduling: Status and perspectives. Transportation science, 38(1), 1-18.

[9] Halvorsen-Weare, E. E., \& Fagerholt, K. (2011). Robust supply vessel planning. In Network optimization (pp. 559-573). Springer Berlin Heidelberg.

[10] Madeira, A. G., Cardoso, M. M., Belderrain, M. C. N., Correia, A. R., \& Schwanz, S. H. (2012). Multicriteria and multivariate analysis for port performance evaluation. International Journal of Production Economics, 140(1), 450-456. 